\title{
The 2019 General Election and the Transparency Question in Nigeria: Political Party Financing As the Bane of Youth Participation
}

\author{
O Babayo Sule ${ }^{1}$, Usman Sambo $^{2}$, Yoserizal Saragih ${ }^{3}$ \\ ${ }^{1}$ Department of Political Science, Federal University of Kashere, Gombe. Gombe State \\ 2Department of Public Administration, Yobe State University Damaturu, Nigeria \\ ${ }^{3}$ Universitas Islam Negeri Sumatera Utara, Indonesia \\ Email: babayosule@gmail.com, ussambo2@gmail.com,yosesaragih77@gmail.com
}

\begin{abstract}
:
Election is perceived as the most peaceful means of power transfer in a democratic setting. It enables for competitive struggles to secure power in a prescribed rule of the game constitutionally. Nigeria is a democratic state currently undergoing its longest democratic transition unprecedented in the history of the country where six consecutive uninterrupted General Elections were conducted. However, the major issue of concern with Nigeria's democratisation is youth participation and exclusion from politics. A major factor behind the marginalisation of youth is linked to the transparency question in terms of party financing and money politics. This study examined critically how the process of party financing excluded Nigeria's youth from participating in the 2019 General Election. The study used a qualitative case study method. Data were gathered from primary and secondary sources. The primary sources included an in-depth interview with relevant stakeholders in the field, direct participant observation and consultation of government's primary documents. The secondary sources were books, journals, newspapers, reports from organisations and agencies and internet sources. The data collected were discussed and interpreted using statistical techniques of tables, charts and a model. The work discovered that youth were barred from participating in Nigeria's 2019 General Election in terms of contesting and winning of elective seats emanating from heavy use of money in party financing and campaign expenditure. The study thus, recommends that the viable alternative for youth to participate in Nigerian politics actively is to establish parties and lower the cost of obtaining party nomination and contest.
\end{abstract}

Keywords:

general election; Nigeria; party financing; transparency; youth participation

\section{Introduction}

Election is a machinery in which democratic governance is operated. It is a peaceful way of transferring power based on the citizens' majority choice. It is anticipated that democracy should be accountable and transparent because of the way in which the leaders emerged by allowing the leaders to compete for power using persuasion and at the same time to give the liberty and freedom of choice by the electorates (Smith, 2012). Most of the countries of the world today operate electoral democracy (Buttorff, 2019). Africa is currently in a state of democratic renewal due to the intensified internal and external pressure for most of the countries to allow for an enabling environment suitable for democratisation (Adejumobi, 2015). Nigeria is one of the success stories of Africa's democratisation in which the transition to civilian rule in the Fourth Republic (1999-2020) witnessed the longest democratic rule in the history of the country unprecedented. In the Fourth Republic, six (6) consecutive elections were conducted successfully which indicates that democracy has come to stay in the country expectedly (Page \& Tayo, 2018). 
One of the areas of concern in Nigerian democracy is the question of transparency and youth participation (European Union, 2019). Party financing is a phenomenon that is being critically and closely watched by electoral bodies of the world to compel compliance and ensure transparency and credibility of elections globally (Institute for Democracy and Electoral Assistance, 2014 and Transparency International 2015). In Nigeria, there are set rules and regulations for party financing and campaign expenditure to encourage accountability, transparency, credibility and integrity of electoral process and general elections in the country (Sule, Azizuddin, Mat \& Ibrahim, 2019). However, the constitutional provisions themselves do not support the youth participation because even the set limit for campaign spending is seemingly beyond the reach of the youth category (Sule, Azizuddin \& Mat, 2018). But this has not been the problem. The problem is that the entire electoral process in the country from party primaries and nomination to the general election weed out the youth due to influence of money politics, bribery, corruption, excessive spending, violation of rules in terms of vote buying and financial recklessness (Sule, 2019). This study examined critically one of the most influencing factors that blocked the Nigerian youth from participating in politics which is lack of transparency in party financing. There may be several reasons why youth are finding it difficult to penetrate political positions in the country. This study limits its perspective on party financing as the premise of analysis.

\section{Review of Literatures}

The literature was critically reviewed based on some fundamental issues on the subject matter of study including Examination of the 2019 General Election; Overview of Party Financing, Party Financing in Nigeria; A Review and Youth and Political Participation in Nigeria.

\subsection{Examination of the 2019 General Election}

The 2019 General Election is perceived as a deepening of democratic practice in Nigeria because it added the tally of the consecutive uninterrupted general elections in the Fourth Republic to six (6). The Election is heralded by political rigmaroles and challenging issues which were recorded previously in the past elections (YIAGA Africa, 2019). Such issues included the controversies in party primaries, court litigations in post-primaries, vote buying and bribery during the party primaries, postponement by the electoral body; the Independent National Electoral Commission (INEC), politics of decamping and characterised violence during the General Election (Sule, Umar \& Sambo, 2020). The INEC registered 92 political parties and 73 of them contested for the Presidency but the contest was a clear battle between the ruling APC of Muhammadu Buhari and the major opposition PDP of Atiku Abubakar. The results indicated that the APC candidate secured $55.54 \%$ of the total votes, the PDP scored $41.18 \%$ while other parties scored 3.28\% (Sule, 2019). In the Governorship election, election was held in 29 states out of the 36 and the ruling APC won 15 while the main opposition PDP won 14. In the National Assembly, at the Senate chamber, the APC won a total seat of 66, PDP 43 and YPP 1. In the House of Representatives, APC has 222 seats, PDP 118, APGA 9, ADC 3, PRP 2, AA 2, SDP 1, ADP 1, LP 1 and APM 1. The results in general indicated a landslide victory for the ruling APC. However, there were allegations and reports from opposition, international observers and this study also report that violence characterised the process and rigging particularly in the gubernatorial election in some states. The process of party financing is still obscured and no report or audited financial statement is forwarded to the INEC till the time of writing this work. This has been confided in the researchers by the informants consulted in various categories. There is a seemingly brazen violation of spending limit and the sources are yet to be determined or ascertained whether it 
is a legal or illegal source (Sule, 2019). It is the unlimited use of state resources and excessive spending that is the major constraint to youth participation in the Election as reported in later part of this work.

\subsection{Overview of Party Financing}

Political party financing even in mature democracies is associated with scandals, and in others a high cost of politics which is eliminating competition (Yadav, 2011). This development compelled many governments to enact new laws to regulate or to amend the provision of their laws towards countering excessive spending and money politics through the introduction of some measures and reforms such as transparency, disclosure, expenditure and contribution limits as well as subsidies to parties and candidates (Alexander, 1989). The most difficult task in party financing is the task of definition and the logic of limitation because the term is contextual and contested (Organisation of Economic Cooperation and Development, 2013). Ferguson (1995) believes that the investment theory of party competition derivation determines the nature and pattern of party financing in America and other developed countries. Parties received excessive funding through competitive struggles from the investors' beneficiaries. Political party financing is a cartel of party business and power struggles where the elites provide a means of securing power through ways that are questionable in terms of transparency (Piccio \& Van Biezen, 2018). Wulff (2017) suggests that the legal framework for party financing in Sub-Saharan Africa, East Africa, North Africa and South Africa is still weak and is envisaged with corruption, abuse of state resources, illegal sources and lack of transparency. This has corroborated an earlier study by Bryan \& Baer (2005) conducted in a study of 22 countries with most of them from Africa and few from other continents. The study by Bryan et al. (2005) established that the process of party financing in the selected countries studied is enshrouded in bribery, corruption, abuse of state resources, excessive funding, clientelism and patrimonialism especially in Africa.

Money is essential in democracy and in steering the affairs of political parties because it determines who gains access and influence (Aspinall, 2019). Political party financing is accompanied with corruption. Many countries have experienced major scandals involving parties in their sources of funds and the effects of their financial support (Williams, 2000). Walecki (2015) further submits that greater part of political funding is "irregular or illegal". Scandals involving party financing is reported in US in 1972, Italy 1992, Germany 1999, Brazil 2005, UK 2006, Finland 2007, France 2011, Japan 2011 and Spain 2013 (Walecki, 2015). Additionally, Sule, Azizuddin \& Mat (2018) reported a similar scandal in Nigeria in the 2015 General Election. Such a scandalous corrupt party financing globally involves funding from infamous sources, demanding contributions from servants, political contributions for favours, contract and policy change, foreign private sector, limiting access for funding to opposition parties and abuse of state resources. Politics is a business which relates to vote buying using state resources in many cases. Thus, corrupt practices in party financing can be regulated through the civil society, media, voters, independent political finance regulator and party's internal control (Walecki, 2015). Additionally, Walecki (2017) and Hutagalung (2019) reported that public funding is the major solutions in some countries with a specific reference to Political parties in Muslims majority societies. Money and politics cannot be separated in modern democracies and this uncontrollable phenomenon is what is leading to a serious campaign finance reforms to foster transparency in the electoral process (La Raja, 2008). A study on the funding of political parties and election campaigns reported a global phenomenon of corrupt practices, irregularities, violation of regulations and excessive spending with the African continent as the worst hit in the process (Falguera, Jones \& Ohman, 2014). A follow up research to the above by IDEA (2016) disclosed the level of progress in terms of the state of funding of parties in Africa. The situation revealed that lack 
of reform of regulatory frameworks and low level of compliance on the existing rules are the major problems of party financing in Africa. Vote buying, abuse of state resources, lack of disclosure of sources of private income and weak oversight and enforcement of rules are the practices that violated party financing regulations in Africa (IDEA, 2016).

\subsection{Party Financing in Nigeria}

Party financing in Nigeria is a process that has been taking place since the attainment of political independence in 1960. The democratic experiment in the country is being frustrated by incessant and intermittent military coups in 1960s, 1970s, 1980s and even in 1990s (Sule, Azizuddin \& Mat, 2017). Just like other parts of the world including the advanced democratic countries, party financing in Nigeria is characterised with illegal funding, bribery and corruption, abuse of state resources and violation of regulations (Sule, Azizuddin \& Mat, 2018). Fortunately, Nigeria is one of the African countries with well-articulated regulations for party financing in the Nigerian 1999 Constitution as Amended and in the Electoral Act 2010. Section 225 (1,2,3,4,5 and 6) and Section 226 (1,2 and 3) of the Nigerian Constitution provide for a detail sources of finance, legal sources, disclosure and auditing as well as scrutiny of the party's campaign expenditure. Section 88 ( $a$ and b) of the Electoral Act 2010 provide for campaign expenditure offences and sanctions, Section 89 (1,2,3 and 4) provide for auditing and scrutiny of the party's and candidates' sources of finance and expenditure within a stipulated period of a time after the election. Section 91 (1,2 and 3) and Section 92 (1,2,3,4,5 and 6) of the Electoral Act 2010 provide for the maximum spending limit of all electoral offices in Nigeria (Sule, 2018). Party financing laws were inherited from the British Order-inCouncil LN 117 of 1958 which clearly identified the candidates and their parties as the financiers of their campaign expenditure. Two major cases of corruption were recorded in the First Republic (1960-1966) in party financing involving National Council of Nigerian Citizens (NCNC) and Action Group (AG) members. In the Second Republic (1979-1983), the 1979 Constitution in Section 205 provided for government's grant to parties. The Aborted Third Republic (1990-1991, popularly tagged 'aborted' because the process of transition was started by the Military Regime of Babangida in 1989 but the final election was annulled on June 12, 1991), politicians and their parties were mainly the sources of campaign financing even though, the government provided some grant for members (INEC, 2005). In the Fourth Republic, the parties were given grant from 1999 until it was abrogated by INEC in the 2010 Electoral Act which identified private funding and other related sources as the legal sources for campaign expenditure. The process of party financing in the Fourth Republic is accompanied with corrupt practices and violation of regulations as observed by many scholars (Walecki, 2003; INEC, 2005; Lawal, 2015; Aghara, Nwaizugbo, Chukwuemeka \& Onyeizugbe, 2015; Olorunmola, 2016; Sule et al. 2017; Sule, 2018; Sule et al. 2018, Sule et al, 2018 and Sule et al. 2019). Money politics, clientelism, vote buying, bribery of INEC officials and other stakeholders, excessive spending, abuse of state resources by ruling parties and violation of financing regulations are the major hallmark of party financing in Nigeria.

\subsection{Youth and Political Participation in Nigeria}

Youth is the most productive segment of the population in any society. Societal progress and development are built based on plan for catering of youths' needs and development (Khokhar, 2017). The United Nations (2018) defined youth as the section of a country's population which falls within the age category of 14-25. Tekindal (2017) and Ibezim (2019) identified youth as the age of transition and seeking. Africa is the global centre of youth population where it is estimated that by 2050 the population of the youth would be 830 million equivalent to $63 \%$ of the total population (UNDP, 2018). Nigeria is one of the countries in the world that has the dominant youth population. Out of the estimated 200 million population, more than half is youth within the age category of less than 30 (Mbah, 
2018) and the country's average median age according to United Nations (2018) is eighteen (18). However, the political offices in the country are dominated by the older ages in the category of age bracket fifty (50) and above which marginalised the youth in the process. Political participation is the process of direct or indirect involvement in the process of political activities such as party membership, voting, support, policy input and contest for a political position (Sloam \& Henn, 2019). For the purpose of this study, youth political participation is restricted to contest and winning of a constitutional elective office. Youth political participation in Nigeria was remarkable during colonial rule where the nationalists fall within the age bracket of 20-40 and after political independence for over thirty (30) years where several youths aged 30 and below hold the positions of Heads of State, Ministers, Governors and Senators. However, in the Fourth Republic, the level of political participation among youth in Nigeria is discouraging despite the demographic strength. For instance, $51.1 \%$ of the voters in the 2019 General Election falls within the age category of 18-30 but no single youth within the same age category made it to the Governorship, Senate, House of Representatives within the same age bracket (European Union, 2019). Factors that are attributed as a hindrance to youth participation include money politics, party financing, ethnoreligious politics, socioeconomic situation, political culture and nature of political parties in the country (YIAGA Africa, 2019).

\subsection{Theoretical Framework}

The work adopted the Transparency and Elite Theories to explain the context of the study. The Transparency Theory is from the American perspective in the 1940s and later spread to other parts of the world. It is an attempt to promote good governance, accountability, transparency for both the leaders and the electorates (Shrivastava, 2015). Transparency Theory has three fundamental propositions: the first assumption is that the level of transparency of the government towards its citizens is a measurement for understanding democracy and governance in that country; the second measure is democracy is measured by a scale of transparency of the political actors in the political field and the third proposition is transparency is not the exclusive right of democracy only though it is mostly easily measured in a democratic setting than in other forms of governments.

The Elite Theory came into being in the 1930s from the Italian Sociologists Vilfredo Pareto (1939), Gaetano Mosca (1939), Roberto Michel (1949) and Political Scientist Ortega (1932). The Theory assumed that society is divided into two main groups: the elite and the masses. Unlike the Marxist' contradiction and antagonism, Elite Theorists postulated that there is a harmony because the elite is coordinated, organised, intellectual and skilful in manipulating their way into power in the society. The minority few elite class is influential in decision making, power control because they are politically developed and economically advanced. Through the prowess of political and economic power, they tend to dominate politics in the society using some shrewd process. Mitchel (1949) advanced that the 'Iron Hand of Oligarchy' is sometimes necessary to compel obedience and support by the elite against the masses.

The above two theories are applicable within the context of this study. The Transparency Theory which explains that a country's democracy can be measured by its level of transparency indicates that the non-transparent and corrupt party financing process in Nigerian election is affecting its democracy including youth participation despite their numerical strength in voting process. On the other hand, the Elite Model disclosed in this study that the elite in Nigeria are utilising their access to power and economy to continue to manipulate their way onto power even in a condition where they are the minority few with a disadvantage in terms of voting age since the vulnerable youth is the majority. 


\section{Research Methods}

The study adopted the qualitative case study approach as a methodology for data collection and data analysis. It is a qualitative case study because the study emphasises its analysis on a particular area of study which is Nigeria and a specific case which is that of the party financing and youth participation in the 2019 General Election (Simmons, 2014 and Lune \& Berg, 2017). The study collected data from two major sources: primary and secondary sources. The primary sources consist of an in-depth interview with some selected informants among the relevant stakeholders in the area and subject matter of study. In this category, five (5) different groups were interviewed. The first category is national party executive from the two major contending parties in the 2019 General Election which are two (2) each from APC and PDP. The second category is politicians where six (6) of them were selected and interviewed also from the two (2) parties of APC and PDP who contested for a seat at the national level based on access to them. The third category is the INEC senior officials where three (3) of them were interviewed. The fourth category is the academics where three (3) senior academics who are expert in the area of study were identified and interviewed. The last category is the members of civil society organisation where six (6) of them were selected from those that are based in Abuja which is the capital of Nigeria. A total number of twenty-two (22) informants were selected in this category. This is justified by Sharan (2009) and Creswell (2014) on the adequate number of informants for an interview in a qualitative research. The questions were designed separately for each group in a semi-structured mode to enable for a flexibility of response. The second primary source is direct participant observation where the authors themselves served as collation officers in various constituencies during the Presidential, National Assembly, Gubernatorial and State House of Assembly Elections in their respective States. They secured a first-hand information based on observation and participation. The third primary source is the government's document including the Nigerian 1999 Constitution as Amended and the Electoral Act 2010. The secondary sources are documented materials such as books, journals, official statistics, reports from agencies and organisations and internet sources (Scott, 2006). The data obtained from the field were discussed and interpreted using statistical techniques such as tables, charts and a model in relation to the previous findings in the field and the application of the theoretical framework.

\section{Results and Discussion}

In this part of the study, the data obtained based on the information from the field work and existing works were discussed, analysed and interpreted for findings and contribution to the body of knowledge.

\subsection{Money Politics and Party Primaries}

Money politics and party primaries is one of the major reasons why youth are excluded in political participation in Nigeria. The entire process of party primaries and general election is affected by lack of transparency in terms of the use of money by the dominant elites to buy their way into power. All the informants that were interviewed in the study from category A, B, C, D and E confessed that excessive use of money in primaries and vote buying in the 2019 General Election affected the process. Many scholars (Abba \& Babalola, 2017; Adekeye, 2017, Page et al. 2018; Verjee, Kwaja \& Onubogu, 2019) support the above notion that the process of party primaries in the build up to the 2019 General Election is influenced by heavy use of money. A study by Sule (2019) disclosed the views of many Nigerians on how the ruling APC and the Opposition PDP used money in a non-transparent way during the party primaries and the preparation towards the General Election in 2019. This is a great factor that dislocated the youth who are not rich enough to compete and survive in a money-laden Nigerian politics. 
The above views correspond to the assumptions of Transparency Theory that Nigerian party financing is not transparent and the Elite Theory which suggests that the dominant ruling class always have their way in terms of dominating the political arena. The cost of ticket alone in party primaries of the two (2) major contending parties revealed that the Nigerian youth who are living in an economically-volatile environment cannot afford to contest. This is presented in table 1 below.

Table 1. Comparative Cost of Ticket for Party Primaries in APC and PDP

\begin{tabular}{lll}
\hline Position & APC & PDP \\
\hline Presidential Ticket & N45 million & N12 million \\
Governorship Candidate & N22.5 million & N6 million \\
Senate & N7 million & N4 million \\
House of Representatives & N3.85 million & N1.5 million \\
State House of Assembly & N850,000 & N600, 000 \\
\hline
\end{tabular}

Source: Lawal 2018

4.2 Legal Provision for Campaign Expenditure: How Adequate and Feasible for Youth? The constitutional provision for campaign expenditure in Nigerian election is provided by Section 89 and its Sub-Section in Electoral Act 2010. This is presented below in the table.

Table 2. Legal Provision for Campaign Expenditure of Electoral Offices in Nigeria

\begin{tabular}{ll}
\hline Position & Spending Limit \\
\hline Presidential Candidate & N1 billion $(\$ 3,183,870.91$ million) \\
Governorship Candidate & N200 million $(\$ 636,774.18$ thousand) \\
Senatorial Candidate & N40 million $(\$ 127,354.84$ thousand) \\
Member Federal House of Representatives & N20 million $(\$ 63,677.42$ thousand) \\
State House of Assembly Members & N10 million $(\$ 31,838.71$ thousand) \\
LG Chairman Candidate & N10 million $(\$ 31,838.71$ thousand) \\
LG Councillorship Election & N1 million $(\$ 3,183.871$ thousand) \\
\hline
\end{tabular}

Source: Electoral Act 2010 Section 89 (1)

There is an argument (Sule et al. 2019) that the current provision in terms of campaign expenditure is not feasible considering the nature of Nigerian politics which is influenced by money. However, all the informants consulted in categories A, B, C, D and E disclosed that the Nigerian youth could not afford such money for undertaking the responsibility of their campaign if they contest for a political office. The most annoying discovery is that the politicians have been spending in multiple of more than the set limit right from party primaries because INEC is not properly monitoring and sanctioning them as provided in Section 89 (2) of the Electoral Act 2010 (Sule, Azizuddin \& Mat, 2017). If the youth could not afford the current legal provision and the provision is inadequate if transparency is to be maintained, then this study can submit that youth are excluded from participation in Nigerian politics financially. Such views supported the submission of Transparency Theory that the process of a country's democracy is used to measure its level of governance and it has also reiterated the Elite Model assumption of the domination of the political field through sublime ways by the ruling elite. 


\subsection{Youth and the Level of Participation in the 2019 General Election}

The information obtained from the field revealed that the youth is the highest section of the population of voters in Nigeria but it has ironically turned out to be the most marginalised section in holding higher political offices. The following model is the summary of the elective offices and the age bracket of the holders according to the obtained views from the informants.

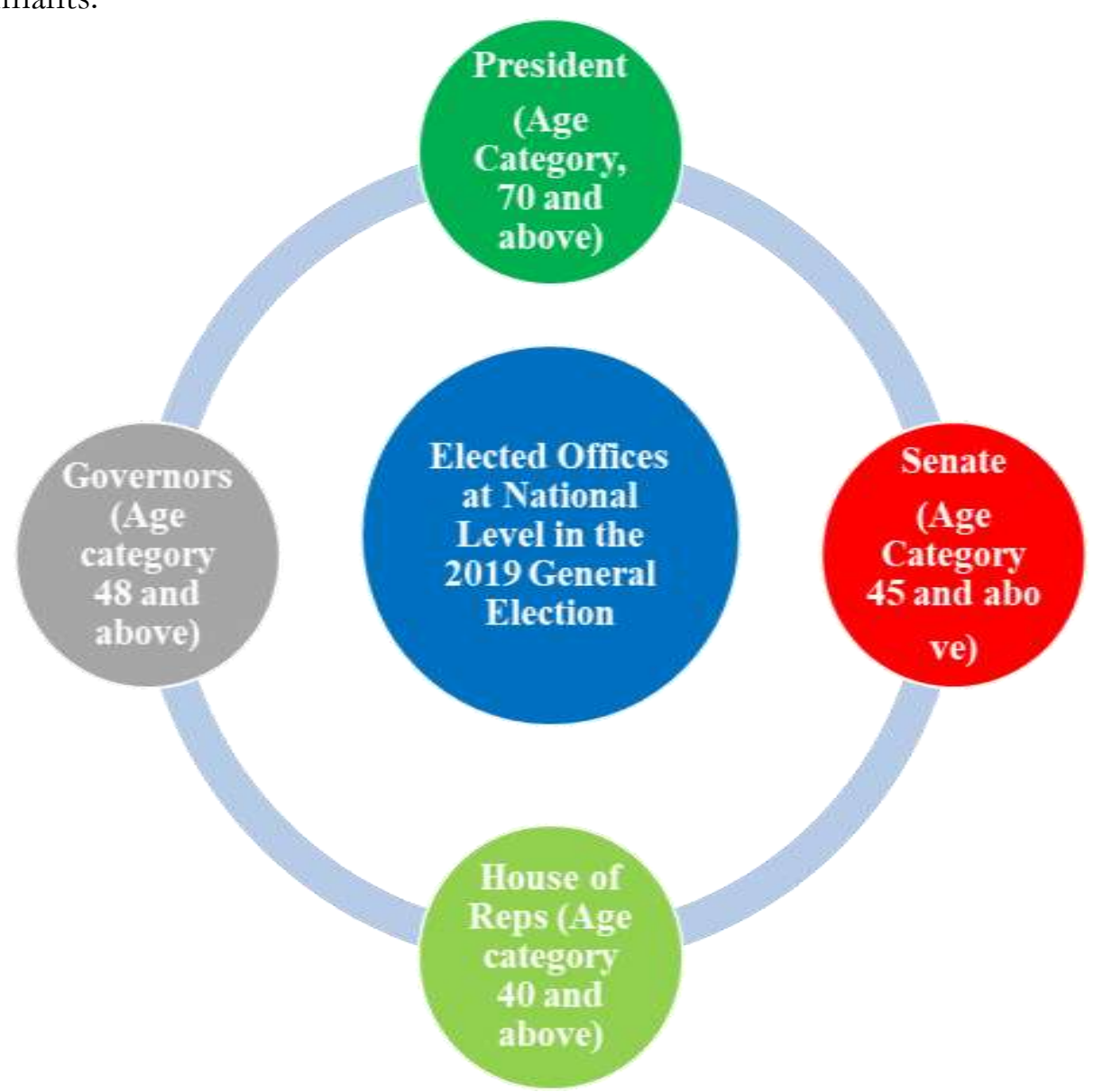

Figure 1. Showing the Elective Office Holders and the Age Category in Nigeria's 2019 General Election Source: Data from field survey converted into a model by the authors 2020.

The above disclosed clearly that youth are totally excluded from participation in Nigerian politics in terms of contesting for top political offices drawing from the United Nations age bracket of youth by conceptualisation which is 14-25. Even a broader and a more flexible definition of youth provides for example by Quran (Chapter 46 Verse 15) from Islamic perspective of 18-40 years is still inadequate for the Nigerian youth to break through. This is inspite of having the highest category of voters of $51.1 \%$ of the total registered voters. This simply means the youth are not voting for their fellow youth due to influence of money politics because the youth do not have enough money to compete favourably with the older age categories.

\subsection{Party Financing and Youth Exclusion in Politics: A Transparency Question}

Party financing is considered by most of the informants as the bane of youth participation in politics in Nigeria particularly in the 2015 General Election as indicated in figure 2 below 


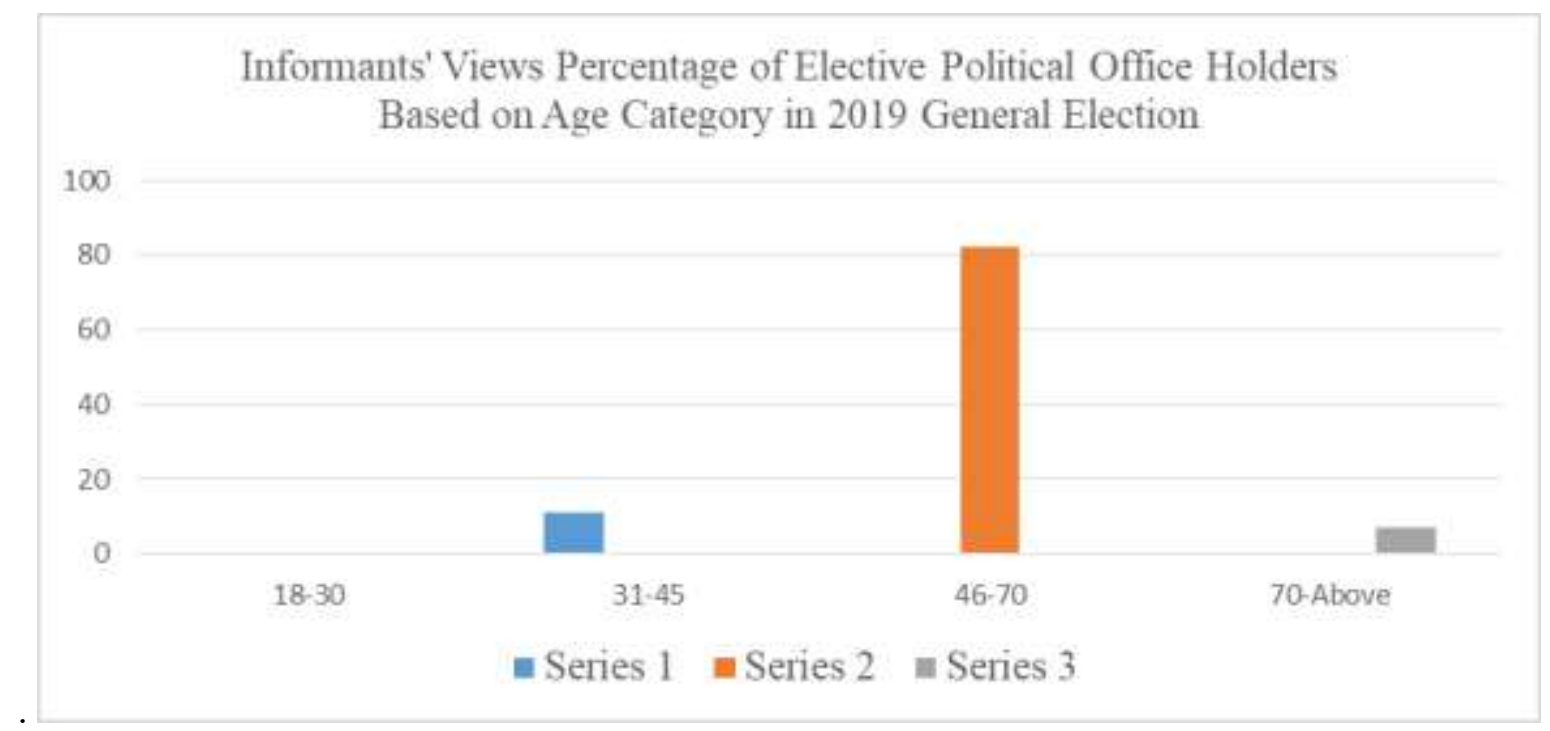

Figure 2. Summary of Informants' Views on the Percentage of Elective Political Office Holders Based on Age Category in the 2019 General Election

Source: Field Survey 2020

Additionally, to support the above statistics, the views of informants classified and summarised revealed that money politics and party financing are the reason why youth could not participate in Nigerian politics in the 2019 General Election.

\section{Views of Informants on the Factors that Prevent Youth from Political Participation in the 2019 General Election}
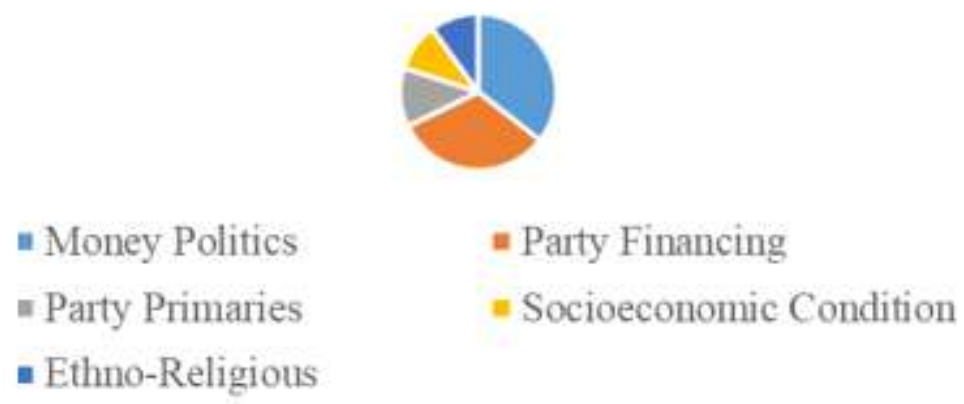

Figure 3. Summary of Informants' Views on Factors that Inhibit Youth from Participation in the 2019 General Election

Source: Field Survey 2020

It is a clear indication that the stakeholders and informants with a high degree of information on the process and conduct of the 2019 General Election agreed that money politics and party financing are the major factors that inhibit youth from participation in politics in Nigeria. 


\section{Conclusion}

The study conclude that the issue of transparency is the major reason behind the youth exclusion from participation in Nigerian politics especially in the 2019 General Election. This is because the process of party primaries, party financing, General Election and the socioeconomic situation in the country could not allow for the youth to compete with the septuagenarians that dominate the political arena for several decades. Thus, for the youth to participate in Nigerian politics accordingly, the study recommends that the youth should utilise their demographic strength to establish a youth party and make the cost of obtaining nomination forms for party primaries affordable based on the youth's financial status. There should be an intensified campaign against money politics by the media, civil society, academics, intellectuals and international donors.

\section{References}

Abba, S.A., \& Babalola, D. (2017). Contending Issues in Political Parties in Nigeria. Africology: The Journal of Pan-African Studies. 11(1), 118-134.

Abdullahi, Y.A. (2010). The Holy Quran: Translation, 6th Edition. London: Krause Books.

Adejumobi, S. (2015). "Democratic Renewal in Africa: Trends and Lessons Learned", in Adejumobi, S. (Ed.) Democratic Renewal in Africa, pp. 1-20. New York: Palgrave Macmillan.

Adekeye, M.A. (2017). "Party Primaries, Candidate Selection and Intra-Party Conflict in Nigeria: PDP in Perspective. Covenant University Journal of Politics and International Affairs. 5(1), 22-39.

Aghara, V., Nwaizugbo, I., Chukwuemeka, E., \& Onyeizugbe, C. (2015). "Changing Perspectives in Politics Marketing in Nigeria". Review of Business and Finance Studies, 6(2), 105-115.

Alexander, H.E. (1989). Comparative Political Finance in the 1980s. New York: Cambridge University Press.

Aspinall, E. (2019). "Jokowi, Masalah Ketidakmerataan dan Demokrasi di Indonesia". Siasat: Journal of Religion, Social, Cultural and Political Sciences. 4(4), 9-14.

Buttorff, G.J. (2019). Authoritarian Elections and Opposition Groups in the Arab World. New York: Palgrave Macmillan.

Bryan, S., \& Baer, D. (2005). Money in Politics: A Study of Party Financing Practices in 22 Countries. Washington: The National Democratic Institute for International Affairs.

Creswell, J. W. (2014). Research design: Qualitative, Quantitative \& Mixed Methods Approaches. California, USA: Sage Publication.

European Union (2019). European Union Election Observation Mission: Final Report. Abuja: EU.

Falguera, E., Jones, S., \& Ohman, M. (2014). Funding of Political Parties and Election Campaigns: A Handbook on Political Finance. Stockholm: Institute for Democracy and Electoral Assistance.

Federal Government of Nigeria. (1999). Nigerian 1999 Constitution as Amended. Abuja, Nigeria: Federal Government Publication.

Federal Government of Nigeria and Independent National Electoral Commission. (2010). Electoral Act 2010. Abuja, Nigeria: INEC.

Ferguson, M. (1995). Golden Rule: The Investment Theory of Party Competition and the Logic of Money-Driven Political Systems. Chicago: The University of Chicago Press.

Hutagalung, D. (2019). "Demokrasi dan Sisi Gelapnya: Pengalaman dari Eropa, Afrika, Asia dan Amerika Latin". Siasat, Journal of Religion, Social, Cultural and Political Sciences. 4(4), 40-45. 
Ibezim, E.A.C. (2019). "The Philosophy of Youth Inclusion in Nigerian Politics: Trends, Challenges and Prospects. Journal of Religion and Human Relations. 11(1), 119-136.

Independent National Electoral Commission. (2005). Political Party Finance Handbook. Abuja, Nigeria: INEC Publication.

Institute for Democracy and Electoral Assistance (2015). Funding of Political Parties and Election Campaign: A Handbook of Political Finance. Stockholm, Sweden: International Institute for Democracy and Electoral Assistance.

Institute for Democracy and Electoral Assistance (2016). The State of Political Finance Regulations in Africa. Stockholm: IDEA.

Khokhar, T. (2017). How is the World Youth Population Changing? World Bank. Retrieved from https://blogs.worldbank.org/opendata/chart-how-worlds-youth-populationchanging.

La Raja, R. (2008). Small Change: Money, Political Parties, and Campaign Finance Reform. Michigan: Michigan University Press.

Lawal, S. M. (2015). "An appraisal of corruption in the Nigeria Electoral System". European Scientific Journal. 11(25), 1-18.

Lawal, M. (2018). FACT CHECK: How Much do the APC, PDP Nomination Forms Actually Cost? Retrieved from https://www.legit.ng/1190547-fact-check-how-apc-pdpnomination-forms-cost.html.

Lune, H \& Berg, L. (2017) Qualitative Research Methods for the Social Sciences. Edinburgh: Pearson Education Limited.

Mbah, F. (2018). Nigeria: Growing Demand for Youth Inclusion in Politics. Retrieved from https://www.aljazeera.com/news/2018/08/nigeria-growing-demand-youth-inclusionpolitics-180809084233452.html.

Mosca, G. (1939). The Ruling Class. Michigan: University of Michigan Press.

Olorunmola, A. (2016). Cost of politics in Nigeria. Abuja, Nigeria: Westminster Foundation for Democracy.

Organisation for Economic Cooperation and Development (2013). Background Paper. Money in Politics: Sound Political Competition in Government. Paris: OECD.

Ortega, Y.G. (1932). The Revolt of Masses. New York: W.W. Norton \& Company Inc.

Page, M.T., \& Tayo, S. (2018). Countdown to February 2019 a Look Ahead at Nigeria's Election. London: Chatham House, the Royal Institute of International Affairs.

Piccio, D.R., \& Van Biezen, I. (2018). Political Finance and the Cartel Party Thesis. In Mendilow, J \& Phelippeau, E. (Eds.) Political Party Funding, pp.68-83. Cheltelham: Edward Elgar Publishing Limited.

Michel, R. (1949). First Lectures in Political Sociology. New York: Harper TouchBook.

Scott, J. (2006). Social Research and Documentary Sources. In J. Scott (Ed.), Documentary Research (Vol. 1, pp. 23-79). London, England: Sage Publication.

Sharan, M. P. (2009). Qualitative research method. San Francisco, USA: John Wiley \& Sons.

Shrivastava, A. (2015). Theory of Transparency: The Right to Know. California, USA: University of Petroleum and Energy Studies: Bepress Limited.

Simons, H. (2014). Case Study Research: In-depth Understanding in Context. In P. Leavy (Ed.), The Oxford Handbook of Qualitative Research (pp. 455-470). New York, USA: Oxford University Press.

Sloam, J., \& Henn, M. (2019). YOUTHQUAKE 2017: The Rise of Young Cosmopolitan in Britain. New York: Palgrave Macmillan.

Smith, S.B. (2015). Chance, Strategy, and Choice: An Introduction to the Mathematics of Games and Elections. New York: Cambridge University Press.

Sule, B., Azizuddin, M.S.M. \& Mat, B. (2017). "Political Party Financing and Corruption in Nigeria's Fourth Republic: The Case of 2015 General Election”. Arts and Social Sciences Journal 8(4), 2-8. 
Sule, B., Azizuddin, M.S.M., Mat, B. (2017). "Political Behaviour and Voting Pattern in Nigeria's Fourth Republic: The Case of 2015 Presidential Election". Asia Pacific Journal of Education Arts and Sciences 4(4), 1-13.

Sule, B., Azizuddin, M.S.M, and Mat, B. (2017). "Independent National Electoral Commission (INEC) and Campaign Financing Monitoring in Nigeria: The 2015 General Election". Journal of International Studies 13(1), 15-31.

Sule, B. (2018). Political Party Financing and Election Reformations in Nigeria's 2015 General Election: Issues and Impacts. PhD Thesis submitted to the School of International Studies, College of Law Government and International Studies, Ghazali Shafie Graduate School of Government, Universiti Utara Malaysia.

Sule, B., Azizuddin, M.S.M., Mat, B. (2018). "Impact of Political Party Financing on Integrity of 2015 General Election in Nigeria". Tamkang Journal of International Affairs 22(2), $165-218$.

Sule, B., Azizuddin, M.S.M., Mat, B. (2018). "Corruption and Electoral Process in Nigeria: Examining the 2015 General Election”. Journal of Technosocial. 10(1), 1-16.

Sule, B. (2019). "Money Politics and Party Primaries in Nigeria's Preparation Towards the 2019 General Election: The All Progressives Congress (APC) and Peoples Democratic Party (PDP) in Focus". 7th Annual International Conference on Social Injustice. Sociology and Criminal Justice Department, Virginia State University.

Sule, B. (2019). "The 2019 Presidential Election in Nigeria: An Analysis of the Voting Pattern, Issues and Impacts". Geografia Malaysian Journal of Society and Space. 15(2), 129140.

Sule, B., Mat, B., Azizuddin, M.S.M. \& Ibrahim, S.Y. (2019). "Sources of Political Parties Campaign Expenditure in Nigeria's Fourth Republic: Examining the 2015 General Election”. In International Area Studies Review. 22(3), 1-22.

Sule, B., Adamu, U., \& Sambo, U. (2020). "The 2019 General Election: Examining the Issues, Challenges, Successes and Lessons for Future General Elections. International Journal of Social Sciences Perspectives. 6(2), 100-113.

Tekindal, M. (2016). "The Position of the Youth in Political Participation". Sosyal Politika Calismari Dergisi. 17(39), 119-140.

Transparency International (2015). Corruption Perception Index: Transparency International Report. Retrieved on 29th December, 2017 from https://www.transparency.org/cpi2015.

United Nations (2018). World Youth Report: Youth and the 2030 Agenda for Sustainable Development. Washington: United Nations.

United Nations Development Programme (2018). Promise or Peril? Africa's 830 million Youth by 2050. Washington: United Nations.

Verjee, A., Kwaja, C., \& Onubogu, O. (2019) Nigeria's 2019 Election: Change, Continuity and the Risk to Peace. Washington: United States Institute of Peace. Retrieved from www.usip.org.

Vilfredo Pareto (1939). The Mind and Society. United States of America: Harcourt Brace and Company INC.

Walecki, D. M. (2003). Political money and political corruption: Considerations for Nigeria INEC Civil Society Forum. Abuja, Nigeria: USAID Publication.

Walecki, M. (2015). Public Funding in Established and Transitional Democracies. In

Walecki, M., Casas-Zamora, K., Genckaya, O., Ammar, D., Sarkis-Hanna, C., EkmekjiBoladian, K. \& Elobaid, E.A. (Eds.) Public Funding Solutions for Political Parties in Muslim-Majority Parties, pp.25-38. Washington: International Foundation for Electoral Systems.

Walecki, M. (2017). Political Parties and Political Corruption. Stockholm: Organisation for Cooperation in Europe. 
Williams, R. (2000). Aspects of Party Finance and Political Corruption. In William, R. (Ed.), Party Finance and Political Corruption, pp.1-14. New York: Palgrave Macmillan.

Wulff, A. (2017). Legal Framework for Political Parties in Selected Countries of Sub-Saharan Africa. Nairobi: Konrad Adenauer Stiftung.

Yadav, V. (2011). Political Parties, Business Groups, and Corruption in Developing Countries. New York: Oxford University Press.

YIAGA AFRICA (2019). Statement on the 2019 Presidential Election Results. Retrieved from https://www.yiaga.org/yiaga-africa-watching-the-vote-statement-on-the-2019presidential-election-results/. 